Check for updates

The BMJ

Cite this as: $B M / 2021 ; 373: n 902$ http://dx.doi.org/10.1136/bmi.n902 Published: 06 April 2021

\section{Covid-19: Government rolls out twice weekly rapid testing to all in England}

\section{Gareth lacobucci}

Everyone in England will be offered access to twice weekly rapid testing for covid-19 from 9 April in a huge expansion of the government's mass asymptomatic testing programme.

People will be able to order free lateral flow tests online to use at home, access them through their workplace, or obtain them from their local authority or local pharmacies, said the government, "to help prevent outbreaks and reclaim a more normal way of life."

The announcement comes after The BMJ first reported last September ${ }^{1}$ that the government was prepared to spend £10obn (€117bn; \$138bn)-almost as much as the entire annual NHS budget in England - to fund mass testing of the population "to support economic activity and a return to normal life" under an ambitious programme dubbed Operation Moonshot.

Regular rapid asymptomatic testing has since been rolled out to some key workers, universities, and schools despite big question marks over their effectiveness. $^{2-4}$ Ministers said that over 120000 positive covid cases that would not have been found otherwise had been identified since the rollout. It said that widening the offer to the entire population would detect more cases and break chains of transmission.

Matt Hancock, England's health and social care secretary, said, "Around one in three people who have covid-19 show no symptoms, and as we reopen society and resume parts of life [that] we have all dearly missed, regular rapid testing is going to be fundamental in helping us quickly spot positive cases and squash any outbreaks.”

\section{Proper evaluation}

But critics described the approach as costly and unevaluated, warning that it may provide false reassurance.

Angela Raffle, consultant in public health and honorary senior lecturer at Bristol University who has worked for the UK national screening programmes since 1996, said, “Testing programmes must be evaluated before being introduced, and with a rapid infection like SARS-CoV-2 evaluation could be done quickly.

"For some reason even the results of the few pilot projects that have been done have been kept secret or reported in a way that ignores important biases. This initiative will add even further waste of resources to the already low effectiveness UK approach to testing."

Allyson Pollock, professor of public health at Newcastle University and a critic of the mass testing programme, said, "The programme has not been properly evaluated in any population group. The harms and costs are likely to be considerable. It would be better if the government got the basics right and focused on people with symptoms [while] ensuring contact tracing works."

Under the mass testing programme people who test at home will need to register their results online or by calling 119. And, in line with updated guidance issued last week, ${ }^{5}$ those who test positive should self-isolate and order a confirmatory polymerase chain reaction test. People with covid-19 symptoms should continue to book a test online or by calling 119 , the government added.

Susan Hopkins, covid-19 strategic response director at Public Health England and chief medical adviser to NHS Test and Trace, said, "Rapid testing helps us find covid-19 cases that we wouldn't otherwise know about, helping to break chains of transmission. These tests are effective in detecting people who are infectious and therefore most likely to transmit infection to others. They are another tool we now have to help maintain lower infection rates."

But Stephen Reicher, a member of the Sage subcommittee advising on behavioural science, wrote in the Guardian that, unless the government provides more financial support for people who are self-isolating with covid symptoms, "it is largely pointless to offer everyone tests twice weekly.

"The policy might result in huge advantages to those who manufacture lateral flow tests, but is unlikely to deliver much advantage in terms of public health." 6

1 lacobucci G, Coombes R. Covid-19: Government plans to spend f100bn on expanding testing to 10 million a day. BMJ2020;370:m3520. doi: 10.1136/bmj.m3520. pmid: 32907851

2 Torjesen I. What do we know about lateral flow tests and mass testing in schools?BM/2021;372:n706. doi: 10.1136/bmj.n706. pmid: 33741566

3 Wise J. Covid-19: Government uses lateral flow tests to keep children in schools against regulator's advice. BM/2021;372:n148. doi: 10.1136/bmi.n148. pmid: 33452017

4 Griffin S. Covid-19: Lateral flow tests are better at identifying people with symptoms, finds Cochrane review. BM/2021;372:n823. doi: 10.1136/bmj.n823. pmid: 33766893

5 Mahase E. Covid-19: Government U turn means positive lateral flow results will again require confirmatory PCR testing. $B M$ J 2021;373:n892doi: 10.1136/bmj.n892.

6 Reicher S. Offering twice-weekly Covid tests is futile without proper support for self-isolators. Guardian2021 Apr 6. https://www.theguardian.com/commentisfree/2021/apr/06/covid-tests-proper-support-self-isolation.

This article is made freely available for use in accordance with BMJ's website terms and conditions for the duration of the covid-19 pandemic or until otherwise determined by BMJ. You may use, download and print the article for any lawful, non-commercial purpose (including text and data mining) provided that all copyright notices and trade marks are retained. 